\title{
$6 \quad$ Making Space for Learning in the Miracle Stories of Peter the Venerable
}

\author{
Marc Saurette
}

\begin{abstract}
This chapter explores how the monastery served as a site of narrative remembrance intended to inculcate monastic disciplina by examining twelfth-century hagiographic texts produced at Cluny. Peter the Venerable's De miraculis and Ralph of Sully's Vita Petri Venerabilis give evidence of the nominally silent monks trading stories amongst one another, and they both highlight the chapter as a privileged location for sharing useful stories. In his retelling of a divine and demonic visitation witnessed by abbot Hugh of Semur, Peter the Venerable adds a new focus on distinct Cluniac places (chapter, dormitory, and refectory), identified as sites of virtue. Doing so allows him both to advocate for new definitions of Cluniac monasticism and also to imbue key claustral spaces with these innovative ideas.
\end{abstract}

Keywords: Medieval/Middle Ages, monasticism, orality, architecture

\section{Introduction}

Just as a door opens or closes depending on necessity, thus should the door of your mouth be open to usefulness or closed to foolishness and empty words. It should be opened to the brethren for their edification and closed to the distraction of those voicing spiteful words or grumbling. It should be opened to the encouragement of visiting monks and closed to the talkativeness of the meddlesome. In brief, only useful things should be said and heard, and if they cannot be, the hermit should not break his silence. ${ }^{1}$

1 Peter the Venerable, Epistola 20, 40-41: '[U]t sicut ostium necessitate tantum aperitur et clauditur, sic oris tui ostium utilitati aperiatur, nugacitati vel vanitati claudatur. Aperiatur

Long, Micol, Tjamke Snijders, and Steven Vanderputten (eds), Horizontal Learning in the High Middle Ages: Peer-to-Peer Knowledge Transfer in Religious Communities. Amsterdam, Amsterdam University Press 2019 DOI: 10.5117/9789462982949/CHo6 
With these words of spiritual encouragement, Peter the Venerable (abbot of Cluny, r. 1122-1156) advises the Cluniac hermit Gilbert that speech control is a key ascetic practice. Words between monks could educate and edify but could also distract brothers from their spiritual goals or, worse, lead to dissension. Peter builds a spatial metaphor, based on Psalm 140, that depicts the mouth as a door to be guarded carefully - swung open to permit positive communication and kept barred against useless talk. Hermits who lacked the physical walls of a cloister, Peter suggests, must imagine their bodies as an enclosure and its parts analogous to the different precincts of the monastery. ${ }^{2}$ This use of imagined space to teach monastic practices, I argue, is a common pedagogical technique of Peter the Venerable and his monks. ${ }^{3}$

Though directed to a Cluniac recluse, Peter's advice expresses his thinking about the speech suitable to all of his monks. He expected his monks to foster what Scott Bruce calls a 'celestial silence' in imitation of angels. ${ }^{4}$ Except for certain periods when conversation was permitted, a monk's lips were intended to utter only the memorized words of fixed texts in song, chant,

fratribus ad aedificationem, claudatur ad obloquentium vel murmurantium detractionem. Aperiatur ad exhortationem supervenientium religiosorum, claudatur ad verbositatem curiosorum. Et ut breviter dicam, aut audiatur aliquid utile aut dicatur, vel si ista non fuerint, silentii censura a solitario non rumpatur'. I have modified Scott Bruce's translation in Silence and Sign, 48. Subsequent translations are by the author unless otherwise noted.

2 Peter repeats this idea throughout the De miraculis, perhaps most famously in his description of Matthew of Albano: 'He did not abandon, under the pretext of any [pastoral] cares, anything of the offices, of the chants, [nor] of the full Cluniac psalmody. He maintained the observances of the cloister in his palace and, while exposed to the world, he held himself apart from secular vanities - as if in an inviolable enclosure - on account of a commitment to religion made inborn through long and constant practice. He confined himself within himself $[\ldots]$ more solitary than collegial'. Peter the Venerable, De miraculis, book 2, chap. 14, lines 10-16, 124: 'Nichil de officis, nichil de cantibus, nichil de prolixa Cluniacensi psalmodia, quarumlibet curarum pretextu reliquit. Servabat in palatio instituta claustri, et mundo expositus, firmo et longo usu, velut innato religionis proposito, a secularium vanitatibus, se quasi septo firmissimo secernebat. Cohibebat se intra se [...] magis solus quam cum aliis'. Hereafter, this text will be cited by book and chapter number, followed by line and page reference (e.g., book 2, chap. 14, lines 10-16, 124). 3 The metaphor of a door to express the idea that the mouth/lips must be guarded like a door has a long literary and religious tradition, drawing on the biblical texts Micah 7:5 and Psalms 140:3. For close reading of the biblical text and parsing of the Hebrew, see Booij, 'Psalm 141', 97-106. The image is used in many early monastic writings, such as the Homilies of Valerius (a fifth-century monk of Lérins); see homily no. 5 De oris insolentia, coll. 706-709. In chapter eight of the Rule of the Master (Regula Magistri), monks are told, when readying themselves for the great silence of the night, to chant the verse, 'Place, O Lord, a guard on my mouth and a door around my lips' (Ps. 140.3). A final example, in common circulation in Peter's time, was the injunction towards silence/continence in Gregory the Great's Moralium libri, chap. 17.

4 Bruce, Silence and Sign Language, 14. The first sections of my essay are indebted to the conceptualizing of speech and silence provided by Bruce's work. 
prayer, and oral reading. Most speech at Cluny was thus intended to be recollective, not inventive. At set times, however - during chapter meetings or periods designated for unstructured activities in the cloister - monks could freely speak their thoughts so long as they engaged in the kind of 'useful' speech described above. These times, I suggest, form a key part of a monk's development and learning.

The first part of this chapter explores what Cluniac monks would talk about when they had the chance. Normative texts from Peter the Venerable's abbacy suggest that Cluniac monks were unrepentant gossips or grumblers and that their conversations tended to distract from their spiritual goals. Letters and narratives written by and about Peter the Venerable, however, show monks to be members of a vibrant network, exchanging stories with uplifting and edifying messages. The second part of this essay examines a single chapter from Peter the Venerable's Book on Miracles as an example of the Cluniac trade in miracle stories. This retelling of a vision of the Christ child highlights the importance of locating miraculous and hagiographic narratives in the claustral spaces of Cluny as sites of memory. Just as Peter uses a spatial metaphor to clarify monastic practices in his advice to Gilbert, this story uses images of claustral space to commemorate key teachings about Cluniac life.

\section{Locating Speech}

In Peter the Venerable's time, the monastery of Cluny housed a community of 300 to 400 monks - not counting pilgrims or visitors on official business. ${ }^{5}$ Even the intimate claustral spaces intended for the Cluniac brothers teemed with a bustling throng of lay servants going about their work. ${ }^{6}$ As Peter himself acknowledges, 'the regular intrusion of administrative matters and the multitude of visitors' at Cluny made silence difficult to maintain. ${ }^{7}$ To address this concern, he sought to minimize lay presence in the claustral

5 This is a number cited by Peter's statute no. 55 ; Statuta Petris Venerabilis abbatis Cluniacensis IX (1146/7), 85; hereafter cited Statuta.

6 Peter reiterates stricter enforcement of the cloister as monastic space in his statute no. 23: 'On the enclosure of the claustral buildings' (Statuta, 6o). For the twelfth-century servants at Cluny see Constable, 'Famuli and Conversi', 384 . More recently Isabelle Cochelin provides an exhaustive account of lay entry into the eleventh-century cloister of Cluny, in her 'Regardes monastiques sur la double clôture de Cluny' (forthcoming in 2019) - an advance copy of which she kindly provided me while preparing this paper.

7 Statuta, no. 19, 58: 'frequentiam negotiorum et multitudinem supervenientum'. 
precinct and to reduce the times and places in which speech was permissible to monks, as Scott Bruce has shown. ${ }^{8}$ By the middle of Peter's abbacy, speaking freely was not permitted at any time in the churches and chapels, refectories, and dormitories of Cluny and any of its dependencies - even if speech had been permitted there previously. In the cloister, conversation was forbidden 'from Vespers until the third hour (terce) of the next day'. 9 While this injunction suggests that speech was permitted for as much as seven hours a day in the cloister, in practice there were traditionally only two periods allowed for speaking about 'useful things' at Cluny. Ulrich's late eleventh-century customary explains that there were two periods a day allowing conversation: following the prayers after the chapter meeting (just before terce); and after sext (around noon). ${ }^{10}$ As an indication of the Cluniac anxiety about these opportunities for speaking openly, Ulrich cautioned that conversations should be kept brief during these periods. Peter would eventually reduce the two times to one. ${ }^{11}$ During Lent, moreover, Peter required that an unbroken silence be maintained in the cloister. ${ }^{12}$ He conceived of Cluny itself as subject to greater restraint than its dependencies, and his statutes extended the zone of silence to include the infirmary complex, the cemetery, and the cemetery cloister as well as most of the workrooms.

Exceptions to the rule of silence give an indication of what constituted places and opportunities for 'useful' speech at Cluny. Peter's statutes explicitly allow some limited interactions with people inside or outside the monastery when necessary for the practical support of the monastic community. The abbot, claustral prior, and hosteller, for example, were expected to welcome guests and to converse with them. The monks managing the construction zone of the maior ecclesia (Cluny III) and associated worksites were likewise exempted from injunctions for silence so that they could speak with tradespeople and labourers without restriction. ${ }^{13}$ Within the claustral precinct, each workroom had a single master who alone was designated to verbally instruct and manage his workers.

Another kind of licit speech was didactic or disciplinary speech. In the cells of the novices and the attached cloister, the novices and their master were allowed to speak 'where and when they are accustomed to speak' for

Bruce, Silence and Sign Language, 148-150.

Statuta, no. 42, 75: 'ab hora vespertina usque ad horam tertiam alterius diei'.

Bruce, Silence and Sign Language, 26-27, citing Ulrich's Customary 1.12.

Statuta, no. 21, 59 .

Statuta, no. 20, 59 .

Statuta, no. $19,57-58$. 
pedagogical purposes. ${ }^{14}$ Abbots, priors, and the sub-priors (called the 'guardians of order' by Peter) could interrogate and compel spoken answers from monks they encountered at any time in their rounds as long as it was to ensure the maintenance of good order. ${ }^{15}$ Exceptions were also made ad hoc to senior monks of proven discipline to provide corrective speech to delinquents and novices, but most disciplinary action was intended to take place in chapter.

During chapter, monks spoke out about their own and others' transgressions, as well as faced the correction of the community. The time of chapter, as Isabelle Cochelin shows, was also a venue for public announcements and community decision-making. Abbots were chosen there, novices were accepted, the unwell announced their departure to the infirmary, and books, such as the Rule of Saint Benedict, spiritual treatises, and outside correspondence, were read out loud. ${ }^{16}$ Before the twelfth century, oblates had gathered in the cloister and the chapter room to memorize liturgical texts, learn how to read and sing, and imitate the habitus of older monks. ${ }^{17}$ Thus teaching children would have taken place at the very centre of the monastery and their lessons would have resounded in the monks' ears. By Peter's day, however, the reception of oblates had been curtailed and elementary instruction was sequestered into a separate novice complex south of the refectory. ${ }^{18}$ But the chapter still retained its didactic role as a sort of classroom and newsroom for regular monks.

During chapter, Cluniac monks sometimes listened to sermons from visitors or senior monks and then discussed them. Peter writes to the bishop of Thérouanne, for example, to recommend that he should come lecture his monks about their supposed pride. Though Peter's tone is acerbic and facetious, he nonetheless highlights that chapter would be the time and place for such an activity. ${ }^{19}$ Even a late-in-life convert to Cluny such as Peter Abelard taught in chapter. In a consolatory letter to Heloise (c. 1142), Abbot Peter eulogizes Abelard's teaching as follows:

14 Statuta, no. 19, 57-58: 'qui ubi et quando loqui solent loquentur'.

15 Statuta, no. 19, p. 58: subprioribus ordinis custodibus. For more on these figures, see Scott Bruce, 'Lurking with Spiritual Intent', 75-89.

16 Cochelin, 'Discussions au chapître', 337-361.

17 See Isabelle Cochelin and Susan Boynton's contributions to Medieval Monastic Education, chap. 2 and $3,7-34$.

18 Statuta, no. 36, 70-71. New recruits (no less than twenty in age in accordance with Peter's statute 36 ) were strictly segregated into the noviciate space for at least a month (an increase in time from as little as a night in former practice) and thereafter spent most of their time there in communal study and private reading until they were seen as able to join the community of monks. 19 Peter the Venerable, Epistola 102, 262-64. The letter as a whole has the tone of 'If you're talking trash behind our backs, at least have the courage to say it to our faces'. 
He was continuously reading, often at prayer and always silent, except when a friendly conversation with his fellow monks [ fratrum familiaris collatio] or a public speech [publicus sermo] to them in chapter about holy matters compelled him to speak. [...] His mind, his tongue, his actions were always cultivating, teaching and saying holy, philosophical and learned things. ${ }^{20}$

For someone so concerned with the dangers posed by speech, it seems a bit surprising that Peter the Venerable praises the teaching of someone who only entered Cluny after being condemned for heretical thinking and being sentenced to perpetual silence at the Council of Sens (1141). ${ }^{21}$ While this was a punishment Peter the Venerable successfully petitioned Pope Innocent II to revoke, it seems telling about the diversity of speakers who might address the chapter at Cluny.

The chapter also seems to be a place for news to be disseminated and stories told. In Peter the Venerable's Book on Miracles, we see the public proclamation of Matthew of Albano's decision to enter the monastery to take place there. ${ }^{22}$ In his Life ofPeter, Ralph of Sully describes an emotional funeral oration Abbot Peter gave to the monks of Cluny, after having already done so in the chapter of Rueil:

there in chapter this brother [i.e., Peter] repeated the speech about the dead brother filled with compunction, tears and devotion. [...] Again he grieved, again tears flowed from the paternal eyes and he urged his audience to a similar display. ${ }^{23}$

20 Peter the Venerable, Epistola 115, 307: 'Lectio erat ei continua, oratio frequens, silentium juge, nisi cum aut fratrum familiaris collatio, aut ad ipsos in conventu de divinis publicus sermo eum loqui urgebant. Mens eius, lingua eius, opus eius, semper divina, semper philosophica semper erudatoria meditabatur, docebat, fatebatur'. I am modifying Scott's translation (Silence and Sign Language, p. 51) to translate 'in conventu' as 'in chapter'; Cochelin has convincing argued that that conventum and capitulum were often synonymous terms (see 'Discussions au chapître', paragraph 16-19).

21 Mews, 'The Council of Sens': 374-45.

22 See Peter the Venerable, De miraculis, book 2, chap. 7, where Matthew of Albano's conversion to the monastic life at Saint Martin des Champs is recounted joyfully by the prior Theobaldus to a spontaneous gathering of the brothers in chapter. In the De miraculis, book 2, chap. 9, when Matthew of Albano's relationship with his subordinates is described, Prior Matthew would also engage in direct lecture, gathering his monks in the chapter room, and then, after a long speech, admonishing them to improve their lives.

23 Ralph of Sully, Vita Petri Venerabilis, col. 22C: 'Venimus Cluniacum, et ibi Frater in capitulo iterum de fratre mortuo incipit sermonem plenum compunctione, plenum lacrymis, plenum devotione. [...] Iterum luctus, iterum lacrymae a paternis oculis fluunt et audientes ad consimilia invitant'. 
This passage highlights the chapter as an intimate space for the monks to express their emotions and speak without being observed by outsiders. It also makes clear that stories told in the chapter were expected to teach models for behaviour. In the chapter and in the noviciate, therefore, more opportunities to engage in didactic learning were possible than the statutes might suggest. When the discussions started during the chapter meeting moved outside into the cloister and the time for free conversation began, however, Peter was worried about what might happen.

\section{Silencing Dangerous Speech}

Open conversation was worrisome to Peter the Venerable, who may have witnessed or perhaps even just feared the possibility that his monks might damage their reputation or, worse, might disrupt the harmony of the monastery with a few infelicitous words. 'By filling the whole day with trifling words', Peter condemns, monks 'may be seen as no different from lay people', indicating that idle words could distract monks from their spiritual focus but also had the potential to damage the monks' public image. ${ }^{24}$ More dangerous than unproductive or idle conversation (nulla prorsus eius utilitas) were the 'harmful' words (perniciosum) that might be spoken. ${ }^{25}$ Peter condemns the monks who spend their time gossiping, grumbling, and sowing dissension. ${ }^{26}$ Idle conversation should be condemned, Peter remarks, because it opens the door to discord:

'idleness', called 'the enemy of the soul' by Father Benedict, resides in so many of us - especially those who are called conversi - such that in the cloister or outside the cloister, apart from reading a little and writing only rarely, either they sleep, leaning against the walls of the cloister [...] and so 'from the rising of the sun until its setting' or rather, almost from the

24 Statuta, no. 42, 75-76: 'integra die nugacibus verbis, aut rebus vacantes, in nullo a saecularibus differre videntur'.

25 Statuta, no. 21, 70-71.

26 Peter also worried about letting servants into the infirmary out of concern they would pass on gossip. See Statuta, no. 24, 61: 'When gossiping to lay persons in the manner of lay people, they reveal the secrets of the monastic regimen, or the regular discipline, which either they saw or they heard from someone, while standing around in their regular duties' ('Praeter hoc etiam illud in causa fuit, quod secreta monastici ordinis, aut disciplinas regulares, quas utpote in regularibus officinis assidue commanentes, vel videbant, vel ab aliis audiebant, more saecularibus divulgantes detergebant'). 
middle of the night at which times one may [do so] with impunity, they fill almost the whole day with vain, hateful words and (what is worse!) even more often with slanderous speech. ${ }^{27}$

Idleness, Peter worries, leads monks to murmur and to attack fellow monks. He was worried not just about the potential spiritual dangers to the monk himself but also about the possible damage to communal harmony. ${ }^{28}$ This last point needs some context to understand what Peter may have feared or knew could happen.

In the early days of Peter's abbacy, silence was a political virtue at Cluny. The statutes we have been discussing above were likely first proposed in 1132 during the aftermath of Cluny's abbatial schism (c. 1125-1126) and the papal schism (1130s), which saw the ecclesia cluniacensis riven by factions. These divisions made Peter sensitive to the potential for divisive speech among his monks. Peter of Poitiers's description of the two schisms in his Panegyric on Abbot Peter and Peter the Venerable's subsequent defence of this work (the Apology for Peter of Poitiers) highlight deceitful speech as the root of monastic disorder. The Panegyric represents the resolution of the abbatial schism (ending with the imprisonment of Peter's rival Pontius) as a successfully muzzling of his opponents:

Now, excellent father [Peter], after you returned the victor from the city [of Rome]

The perfidious tongues of the Pontians are silenced.

The impudent mouths of these dogs quell their rabid barking. ${ }^{29}$

27 Statuta, no. 39, 74: 'Causa instituta huius fuit, quia otiositas iuxta patrem Benedictum inimica animae, in tantum magnam partem nostrorum, eorum maxime qui conversi dicuntur, occupaverat, ut in claustris vel extra claustra, praeter paucos legentes, et raros scribentes, aut adhaerentes claustri parietibus dormitarent, aut ab ipso, ut sic dicam ortu solis, usque ad eius occasum, immo fere mediam noctem, quibus impune licebat, totam paene diem vanis, otiosis, et quod peius est, plerumque detractoriis verbis consumerent'. Constable highlights that in Peter's time, conversi had come to mean something akin to the Cistercian lay brothers, i.e., monks that entered the monastery later in life, may have been illiterate, and had less involvement in Cluny's liturgical life; see Constable, 'Famuli and Conversi'.

28 Other forms of divisive or disruptive speech are specified in statute no. 69, which began the practice of posting guards in the dormitory, since monks' things would go missing, leading to 'a multitude of quarrels' (multitudinem illic convenientium multorum querelae).

29 Peter of Poitiers, Panegyricum Petri Venerabilis, 13-54, lines 250-252: 'Iam, Pater egregie, quia victor ab urbe redisti ,/ Pontionitarum perfida lingua silet. / Ora proterva canum rabidos posuere latratus'. 
Peter of Poitiers's poem is filled with like images of corrupt and harmful speech. Pontius is described as a 'slippery magician' who 'distorted sober hearts', 'played tricks', and 'vomited out black poison' in his speech. ${ }^{30}$ Like a false prophet, Pontius used his deceptive oratory (false news!) to win over the hearts of his followers whom he then convinced to undertake nefarious acts, such as desecrating the cloister of Cluny itself. This invective serves to praise, by juxtaposition, the brilliant truthfulness of Peter's unparalleled oratory and writings. Licit and illicit speech are thus key criteria in the Panegyric for describing why Peter the Venerable was the proper and a praiseworthy leader of the ecclesia cluniacensis.

When Peter of Poitiers's panegyric of his abbot received criticism after circulating, Peter the Venerable wrote a lengthy Apologia (mid-113os) of his monk's right to compose such praises about him. Citing a pseudonymous or lost work of Cicero, Peter the Venerable justifies his hyperbolic praise in usefulness (utilitas). The poem's purpose was licit, he argues, since it worked toward the construction of a stable political order. A much-praised and thus well-loved leader, he concludes, fears no collapse of his republic. ${ }^{31}$ Since praise and political

30 Peter of Poitiers, Panegyricum Petri Venerabilis, 368, 354, 323.

31 Peter elaborates this idea at length in his Apologia; Franz Dolveck entitles this work the Carmen Apologeticum in his edition, Pierre le Vénérable: Poèmes, p. 251-285; here p. 271, lines 223-234:

Cicero knew these things and left his writings for us,

In which the Latin language has great trust,

Whose poverty his tongue enriches thusly with great wealth,

Such that now there is no eloquence more rich.

'The commonwealth', he said, 'stands together with an upstanding leader

And it also falls with his fall'.

It is correct, therefore, to remove sources of disorder

And to draw faithful men to our upstanding leader,

So that, since the stomach of the mind is fed with heavy praise,

The glory of the prince wards off hunger.

And thus it happens that the republic fears no collapse,

When it perpetually renews the men of the prince.

Noverat haec Cicero, nobis quoque scripta reliquit,

Cui multam debet lingua Latina fidem.

Cuius pauperiem sic ditat divite lingua,

Vt iam sit nullum ditius eloquium.

'Publica res', inquit, 'proprio stat principe stante,

Cuius et in casu labitur ipsa simul'.

Convenit iccirco causas remouere ruinæ

Et stanti vires addere continuas.

Vt, stomacho mentis impensa laude refecto

Principis esuriem gloria submoveat. 
stability of the Cluniac republic were Peter of Poitiers's intent, Abbot Peter continues, his words had true merit even if they were, as hyperbole, somewhat untruthful..$^{22}$ The most passionate sections in Peter the Venerable's Apologia are his attacks directed against the critics whom Peter heard criticizing his monk and thus denying the praises of himself. Their transgression is saying and repeating such treacherous words, so they are told to be silent:

Hold your tongue, you shades of Tartarus,

Who - deranged - might speak such wicked words. ${ }^{33}$

Paralleling his advice to Gilbert, Peter's command for them to be silent makes use of a spatial metaphor:

Clamp shut the maw, seal the passageway of your unspeakable voice,

And let the throat swell so that it cannot make illicit sounds.

Fear to be heard or to speak, O Unworthy Voice,

Fade out, I counsel, and restrain yourself by keeping silent.

So that such a racket does not pollute human ears,

You yourself must refrain from taking breath in public. ${ }^{34}$

And later Peter again cites the idea of the mouth as a door, which needs to be barred against harmful speech:

Ahh! Retract these base things which you - so base - vomited out, And do not let them flow; bar your throat with a strong beam. ${ }^{35}$

Sicque fit ut nullum timeat respublica casum,

Cum semper vires principis ipsa novat.

32 One of the key themes of the Panegyric (as reconstructed from Peter the Venerable's Apologia) is falseness; rhythms and rhymes were incorrect (false) and by overly exaggerating his abbot's qualities (untruthful), Peter of Poitiers was lying. The Apologia attributes this interpretation of the Panegyric as a result of literary ignorance, since the critics were not aware, Peter the Venerable accuses them, of the literary tool of hyperbole. A little falseness, Peter the Venerable argues, is fine when it serves a good purpose, in contrast to what Augustine might argue (see Jay Diehl's contribution to this volume for more on this topic). This instrumental conception of language does seem to contradict what he generally argues against his opponents.

33 Peter of Poitiers, Apologia, 256, lines 13-14: 'Manes tartarei talem compescite linguam / Quae demens potuit verba nefanda loqui'.

34 Peter of Poitiers, Apologia, 257, lines 17-22: 'Infandae vocis fauces arctate meatus, / Et tumeat guttur, ne sonet illicita. / Audiri timeas, o vox indigna, sonare, / Consulo, deficias, teque silendo premas. / Humanas strepitus ne talis polluat aures, / Communes usus spiritus ipse nega'.

35 Peter of Poitiers, Apologia, 261, lines 103-4: 'Ha revoca sordes, quas sordibus evomuisti / Neve fluant, forti guttura claude sera'. 
These quotations are just a small sample of the images that Peter the Venerable composes depicting critics as a demonic 'Other' needing to be removed from the body politic. As these passages demonstrate, Peter does not stint in his use of invective to condemn harmful speech. Though addressing an anonymous critic, Peter the Venerable's defence of Peter of Poitiers likely was intended as a general apologia of his abbacy to a wider Cluniac audience - telling them to stop attacking him and his. This early use of invective in Peter's writings serves as a template for similar use in his later treatises against the heretical Petrobrusians, Jews, and Saracens, who are all commanded to be silent and to stop spreading their lies. ${ }^{36}$ Peter, we understand, is no fan of free speech.

\section{Praiseworthy Conversation}

Peter the Venerable's letters, treatises, and statutes provide very little explicit description of what kinds of 'useful speech' should be open to monks. His concerns about negative speech hint at what might, in juxtaposition, be understood to be licit or fruitful. When we see that Peter is worried that idle speech opens the door to dissent, we would expect to see useful speech as leading to monastic harmony or establishing a greater sense of community. These types of speech are precisely what we see in the praise of extraordinary monks and abbots. The hagiographic genre, with its emphasis on edifying spiritual biography, tends to be the best source for explicit descriptions of 'useful speech' dating to Peter's abbacy.

Some 20 years after his death, we see Peter the Venerable commemorated in his Vita as a paragon of productive speech and writing. ${ }^{37}$ The author, Ralph of Sully, a future abbot of Cluny himself, chiefly highlights how Peter the Venerable was a magisterial teacher (and author) who offered his wisdom and erudite learning to an awestruck audience. Alluding to the Benedictine ideal of the abbot as one who teaches by word and example, Ralph describes how Peter sought to create a spirit of brotherhood through his sermons preaching with great emotion and impact (affectu et effectu) - but teaching even more by his acts (praedicando magis actu docebat). ${ }^{3}$ Ralph describes his abbot, however, also as continuously seeking to learn:

$3^{6}$ For more on Peter's use of invective against heretics, Jews, and Muslims, see Iogna-Prat, Order and Exclusion, 347-49.

37 The vita dates to the abbacy of Stephen I of Boulougne (1163-1173) to whom it is dedicated; Ralph would be chosen as the next abbot of Cluny in 1173. Ralph of Sully, Vita Petri Venerabilis, col. 15 B.

$3^{8}$ Ralph of Sully, Vita Petri Venerabilis, col. 19B. 


\begin{abstract}
Abbot Peter surrounded himself with learned men, from whom he, by constantly asking questions, desired to learn, even though everyone thought him already extraordinary in his wisdom. He was not pompous, nor did he present himself as imperious, but instead, as if a little boy, he preferred to learn by ceaselessly scrutinizing divine matters. ${ }^{39}$
\end{abstract}

In this brief moment, Abbot Peter is not a stern father or awe-inspiring preacher but a fellow brother humbled by the world of learning. He is erudite, yes, but still someone who continues to learn in collaboration with his brothers. $^{40}$

As is typical for abbatial vitae, Peter's curiosity is used to mark him as exceptional, but other examples help us understand this sort of productive conversation. Peter's own Book on Miracles describes how wise monks would speak to benefit others. A brother Benedict, for example:

remained perpetually silent unless a serious and precise reason compelled him to speak. His words were brief, removed from trifles, jokes and any words lacking utility. If ever there was a speech about spiritual things, he was never without sighs, never without tears. ${ }^{41}$

Silence here is underlined as the key virtue, but Peter concedes that Benedict's speech was permissible since he maintained a proper brevity and an appropriate emotional disposition - eschewing levity and embracing sadness. A similar description is made of another Cluniac, Gerard, whose mouth 'so strongly emanated the flavour of divine matters, which he had drunk from boyhood, that to attentive observers almost every of his words and deeds smelled only of a heavenly fragrance'. ${ }^{42}$ This vague description

39 Ralph of Sully, Vita Petri Venerabilis, col. 19D: 'Habebat circa se doctores, a quibus discere quaerendo semper cupiebat, cum ipse mirabilis in scientia ab omnibus haberetur. Non elevabatur, nec se magnum faciebat: sed quasi puer parvulus divina scrutando, votis omnibus assidue discere praeoptabat'.

40 The term philosophia was often used to mean the monastic life, such as by Cassiodorus, as it was intended to be a life devoted to the search for wisdom. Jean Leclercq and Caroline Walker Bynum have long emphasized that this idea was widely accepted in twelfth-century monasticism. See Leclercq, The Love of Learning, and Bynum, Docere verbo et exemplo.

41 Peter the Venerable, De miraculis, book 1, chap. 20, 60: 'Silebat perpetuo, nisi cum eum certa et gravis causa loqui cogebat. Verba eius brevissima, a nugis, iocis, atque omni prorsus ociositate aliena. Si quando vero de spiritualibus sermo erat, numquam is sine suspiriis, numquam sine lacrimis fiebat'. 42 Peter the Venerable, De miraculis, book 1, chap. 8, 25: 'Divinarum rerum saporem, quam a puero imbiberat sic tenaciter conservabat, ut cuius pene universa verba vel facta diligenter considerantibus, nil aliud quam celestem fraglantiam redolerent'. 
again seems to highlight that his speech successfully transmitted a feeling of holiness. But when Peter describes his speech, it is highly praised for being recollective, not conversational; Peter goes on to say that Gerard's mouth would never forget a single psalm as he recited the liturgy nor ever leave it unfınished. Peter thus largely considers Benedict and Gerard as vessels for fixed texts - a description that would have left a Cluniac reader of this story without a clear indication of what the holiest monks should talk about. The lengthy description of Gerard, however, ends with a clue of what Cluniac monks might fruitfully discuss. Peter testifies to the veracity of the miracles worked or seen by Gerard, saying: 'Having heard these things from this brother, I cannot doubt the vision, especially when I find that everyone who recounts both of these visions agree in all the details. For the prior of this brother had heard everything about Gerard - he later confirmed the earlier testimony completely'. ${ }^{43}$ Peter reveals a chain of narrative transmission and thus suggests what monks were likely talking about all the time: edifying stories.

Almost every story of Peter's miracle collection and Ralph's Life of Peter identify a source, excepting those viewed by the authors' themselves. ${ }^{44}$ In the opening story of the Book on Miracles, for example, Peter tells us that a peasant who had seen a miraculous vision of Christ told his parish priest about it, who in turn told the bishop of Clermont-Ferrand, who ultimately told Peter. ${ }^{45}$ That Peter carefully notes the name of his sources and evaluates the authority of this witness (or witnesses) suggests that Cluniac monks were used to hearing similar stories and judging their credibility. Offering a source for miracle stories is key to Peter's attempt to establish their authenticity, but has the secondary effect of showing us that Peter and other Cluniac monks loved to commerce in story-telling. Ralph's Life of Peter is much the same, though he is more apt to cite common knowledge than Peter. Ralph recounts, for instance, how Peter the Venerable gave his very best coat (pelliciam suam peroptimam) to a poor woman at the gates of Cluny - something that

43 Peter the Venerable, De miraculis, book 1, chap. 8, 34: 'His a fratre illo auditis, ultra de visione dubitare non potui, quando sic in omnibus concordes utriusque revelationis relatores inveni. Nam quicquid ille prior de fratre illo altero a Gerardo audierat, hoc totum ultimus suo ipsius testimonio confirmabat'.

44 There is a marked difference between the earlier shorter version (c. 1134/5) of the De miraculis and its later additions $(c .1142)$ in this respect. The earlier redaction is very careful to record witnesses, while the long version depends largely on Peter's direct knowledge. The addition of the Life of Matthew of Albano, which fills book 2, chap. 3-23 (long version) does not cite any witnesses other than Peter himself and the praise of Cluny and linked miracle stories (book 1, 12-20) likewise lack witnesses - perhaps because they were all common knowledge at Cluny.

45 Peter the Venerable, De miraculis, book. 1, chap. 1, 7-8. 
became quite the talk of Cluny: 'Although he [Peter] had wished this to be done secretly, the much talked about deed was evident to all marvelling at the charity of the man.' ${ }^{46}$ Ralph, who was likely a monk at Cluny at this time, acknowledges that such stories were open secrets among the monks. In another story in the Life of Peter, Ralph recounts the story of Jordan, a monk of Saint Foy, who was witness to a secret exorcism performed by Abbot Peter. He kept quiet for years until hearing about Peter's death, which released him from his vow of silence. Ralph's description of Jordan breaking his silence is revealing: 'when [Peter's] death was confirmed, in the chapter room of Saint Foy, the monk Jordan publicly revealed the miracle that had occurred and he affirmed that it had certainly happened in many other places'. ${ }^{47}$ This passage suggests that many such stories about Peter were likely hidden under oaths of secrecy. This effectively allows Jordan (and/ or the narrator Ralph) to use this one story to stand in for many unspoken ones. The intimation of the existence of other hidden stories almost seems to give license to others to reveal and record further stories about Peter the Venerable. Thus a story becomes an occasion for more stories.

\section{Miracle Stories and Utilitas}

The hagiographic writings discussed above indicate that Peter and his monks saw the commemoration of virtuous acts as a 'useful' endeavour. Ralph of Sully singles out the Book on Miracles in particular as one of Peter's most important works in this respect, noting, 'Anyone who has read the book that he compiled about various revelations and visions, understands how great is its usefulness and purity'. ${ }^{8}$ Though concise, Ralph of Sully's assessment of Peter's miracle collection acknowledges the considerable value evident to its readers and suggests that Cluniac monks yearned for, sought out, and read the collection of miracle stories. Peter himself presents the Book on

46 Ralph of Sully, Vita Petri Venerabilis, col. 25B: 'Quod cunctis charitatem viri mirantibus licet occulte fieri voluerit, celebre factum apparuit'.

47 Ralph of Sully, Vita Petri Venerabilis, col. 28A: 'Ipse audita autem morte ipsius, Jordanus monachus miraculum, ut factum fuerat, in capitulo Sanctae Fidis publice revelavit, et multis aliis hoc factum fuisse pro certo affirmavit'.

48 Ralph of Sully, Vita Petri Venerabilis, col. 21B: 'Librum quem de diversis revelationibus sive visionibus edidit, quantae puritatis fuerit vel utilitatis, qui legit intelligat'. Ralph, writing during the abbacy of Stephen I of Boulogne (r. 1161-73), bases this judgement on firsthand knowledge of the De miraculis - a usage evident since he reworks stories from the De miraculis in his own Vita Petri Venerabilis. 
Miracles as an attempt to codify the 'useful' stories he had heard but would be forgotten if not written down:

The grace of miracles occupies an eminent position among the spiritual gifts of the Holy Spirit due to its inherently great utility, with the result that chiefly through it the world is freed from the shadows of unfaithfulness, it is given the eternal light of truth, and also in the hearts of many of the faithful to whom at some time the vision [of a miracle] was granted, faith is increased, hope blossoms and charity is strengthened. I often find myself growing indignant that, when hidden by unfruitful silence, miraculous things vanish (which occur in many places and in our times, though less commonly now than previously) because none puts his mind to writing down what, if made manifest, would benefit the readers. ${ }^{49}$

Peter here contrasts 'unfruitful silence' with the action of telling of stories that allow miracles to convert readers to a better life. Written collections of these stories could also continue to have this power long after the author has died, since texts retained the transformative power of miracles. Though Peter imagines his enterprise to be textual, what he says could equally apply to the oral communication of these stories. The medium is not the issue; rather, the content of the stories makes them licit vehicles for mutual edification.

Mirroring Peter's justification for the Book on Miracles cited above, Ralph sees the purpose of his Life of Peter as uplifting Cluniac monks:

Not with presumption but with love, I - the least of all men - will attempt to describe his life which I learned from religious men or I myself saw, leaving aside many more things for my betters [to write about] so that God is honoured, that our infirmity is strengthened by his example, that the Church is elevated in accordance with the grace of its sons, and finally that God is glorified everlasting in his saints, especially those in the Cluniac Church..$^{0}$

49 Peter the Venerable, De miraculis, book 1, prologus, lines 1-11, 3: 'Cum inter Spiritus Sancti karismata, gratia miraculorum non parvam obtineat dignitatem, utpote que tantam in se continet utilitatem, ut maxime per illam et mundus ab infidelitatis tenebris liberatus, et eterno lumine veritatis donatus sit, et adhuc in multorum fidelium cordibus, quibus aliquando hoc videre datur, per eam fides augeatur, spes crescat, karitas confirmetur, indignari sepe soleo, cur ea que nostris temporibus plerisque in locis miracula, licet rarius quam priscis temporibus proveniunt, cum non sit qui ad illa scribenda animum applicet, que prodesse legentibus manifesta poterant, infructuoso silentio tecta dispareant'. 50 Ralph of Sully, Vita Petri Venerabilis, col. 15: 'Quapropter ego minimus omnium hominum, non tam praesumptione quam amore, de illius vita scribere aggrediar, quod virorum religiosorum 
Part of the function of miracle stories and hagiography is public relations, Ralph admits. They provide a means to show that the Cluniac church remains honourable and favoured by God to outsiders. But their primary purpose is to teach better conduct to Cluniac monks.

\section{Cluny's Miraculous Space}

I suggest that Peter intended his lengthy Book of Miracles to address a Cluniac audience based on the miracle collection's content. It focuses on the community of regular Cluniac monks as miracle workers and monastic models. It is filled with original and, as Peter underlines to the audience, the most 'up-to-date' stories about monks, priests, demons, and ghostly spectres..$^{1}$ Visions of the dead mix together with miracles engendered by the Eucharist, the nefarious machinations of demons, and hagiographic narrative..$^{2}$ Peter's specific selection of miracles, however, is telling. The witnesses of visions, the novices tested by temptation, divinely punished sinners, and infirm monks healed through confession are almost all Cluniac. Those saintly individuals excelling in the practice of spiritual exercises are almost without exception Cluniac monks, and the models of spirituality are pertinent only to the monastic world. ${ }^{53}$ The stories also reaffirm traditional Cluniac themes such as the efficacy of intercessory prayers and the sacrality of ecclesial space. Cluny itself is repeatedly praised for being a celestial citadel and earthly refuge, for its unparalleled opus dei, as well as for its unsullied purity. ${ }^{54}$ The dominating presence of Cluniac themes and figures buttresses the evidence of a manuscript diffusion pointing to a Cluniac audience (or at least a readership of Benedictine monks within the orbit of the ecclesia cluniacensis). 55

relatione didici, aut ipse vidi: majoribus majora relinquens, ut et inde Deus honoretur, et illius exemplo nostra infirmitas roboretur, et Ecclesia de filiorum gratia sublimetur, denique Deus in sanctis suis semper glorificetur, maxime in Cluniacensi Ecclesia'.

51 Peter the Venerable, De miraculis, book 1, prologus, line 16, 3 and book 2, prologus, lines 1-3, 93.

$5^{2}$ The task of summing up this text is made difficult given that Peter largely reworked the text ten years after his first redaction, see Peter the Venerable, De miraculis, $57^{*}-86^{*}$ for the historical and manuscript evidence.

53 The end of the third redaction (long version, book 2, 27-29) also contains praise of the Carthusians, with whom Cluny was joined in a prayer confraternity; see Peter the Venerable, Epistolae, ep. 24, 48, 132, 170, 186, and 187 where Peter's relationship with the Carthusians is also discussed.

54 See, for example, the well-known praise of Cluny in book 2, chap. 9, 34-37.

55 See Peter the Venerable, De miraculis, pp. $35^{*}-56^{*}$. 
Not surprisingly, therefore, Cluniac monasteries are the primary sites of miracles recorded in Peter's Book on Miracles, with specific places highlighted as central to the narratives. Solitary monks sleeping in the workshops without permission or new arrivals in the novices' cells, for example, seem to receive the most fearful demonic visitors. Monks in the cemetery encounter the undead. Frustrated demons have a disgusting impulse to leave the monastery through the latrines. Other spaces are recorded not as sites of miracles but as sites of storytelling and remembrance. As we have noted above, the chapter room, for example, is often where news is communicated and didactic stories recounted.

In order to explain the didactic function of these stories, I wish to look in detail at one representative example. Chapter Fifteen of Book One (in Bouthillier's edition) was written during the middle of Peter's abbacy ( $c$. 1142) in the second of three redactions of this text. The claustral buildings act as the hero of the story, in which a Cluniac monk watches a demon try and fail to penetrate the heart of the abbey of Cluny. The moral of the tale is clear - Cluny is a celestial citadel impervious to the devil's attacks. Peter the Venerable's vision-story is worth a detailed look because it teaches what and why the demon cannot penetrate. Peter links Cluny's protection to what regularly happens within the buildings, not necessarily to the place itself.

This story is an almost-complete reimagining - at almost twice the length - of a story in Gilo of Toucy's posthumous Life of Abbot Hugh, written more than 20 years earlier (c. 1120). ${ }^{6}$ The similarities and differences in storytelling are quite revealing about the two authors' intentions and about how the stories functioned to edify their audience. Both versions are frame stories, and both Peter and Gilo set the scene in a similar fashion: all the monks of Cluny are gathered together in the chapter room on Christmas Eve in the year $1108 \mathrm{CE}$. An aging Abbot Hugh enters and tearfully recounts a story about a miraculous vision of the Christ-child on another, earlier, Christmas Eve. ${ }^{57}$ As a story likely well known at Cluny, Peter and Gilo both emphasize that Hugh did not name the witness, but everyone knew it was Hugh himself.

What Hugh is said to have seen and what it is said to mean differ significantly between the two accounts, the first praising Cluny's liturgical

56 Gilo of Toucy, Vita Hugonis Abbatis, 45-109; here book 2, chap. 6, 96-97.

57 Isabelle Cochelin notes that on Christmas Eve everyone at Cluny waits in the chapter room for when the time of the birth of Jesus has officially arrived. At this point they all fall to the floor in prayer. See Cochelin, 'Discussions au chapître', paragraph 13. 
splendour and the second praising the inner devotion of its monks. A subtle difference, perhaps, but one with important ramifications for how Cluniac space is represented and for what Cluniac monks are expected to learn.

In Gilo's earlier version of this story, the Christ-child, the Virgin Mother, and an angelic host are gathered in the Church of the Mother of Mercy at Cluny (the claustral chapel). Gilo cites Jesus's speech directly; more accurately, Gilo cites Hugh citing Jesus. Jesus praises the solemnity of his own feast day in a pastiche of ideas drawn from the hymns and liturgical readings particular to the Cluniac celebration of Christmas Eve. He finishes this speech with a declaration that his birth overturned the power of the devil, who, once invoked, becomes visible to Jesus (but not Hugh). The devil is immediately banished. With the devil cast out, Jesus invisibly celebrates his feast day alongside the monks of Cluny. Gilo's moral is clear - the special liturgical veneration of Christ's nativity grants Cluny itself special protection.

In Peter's retelling, the focus shifts away from the liturgy, but the opening demonstrates some similarities:

It is the custom of this monastery to undertake the Nativity of Our Saviour with a singular affection more devoutly than other solemnities, and to celebrate it through the harmonies of our songs, the prolixity of our readings, and by the lighting of many additional candles as well as - far surpassing these others in importance - with a special devotion and with a great outpouring of tears..$^{8}$

These first lines parallel Gilo's account, highlighting and expanding on the pre-eminence of the Cluniac liturgy. ${ }^{59}$ Both Gilo and Peter underscore the necessity of tears as the proper emotional disposition in celebrating Christmas. Peter argues, however, that it is far more important that the monks experience the feast day at an interior and emotional level than that they sing beautifully, light candles, and perform a lengthy liturgy. In essence, he redefines Gilo's praise of the Cluniac liturgy into an argument

$5^{8}$ Peter the Venerable, De miraculis, book 1, chap. 15, 50: 'Mos eiusdem est monasterii, nativitatem Salvatoris ceteris sollempnitatibus quodam singulari affectu devotius agere, et cantuum melodiis, lectionum prolixitatibus, cereorum multiplicium accensionibus, et quod longe prestantius est speciali devotione, multaque lacrimarum profusione, cum angelicis spiritibus alacriter sollempnizare'.

59 In his statutes, Peter also emphasizes the singular status of Christmas, designating the best wine be served for celebrating communion (Statuta, no. 73) and mandating all monks, without exception, celebrate mass together (Statuta, no. 72). This latter statute indicates that Christmas was viewed as a key feast for gathering the Cluniac community together. 
for internalizing the liturgical experience. After this subtle redefinition of Gilo's opening, Peter highlights further the importance of interior feeling. As the monks readied themselves for Christmas:

the brothers in their accustomed manner prepared themselves and everything necessary and, by ornamenting the church and decorating all the places of the monastery in a similarly suitable fashion, they strove to appear festive both inwardly and outwardly. ${ }^{60}$

Again Peter's account highlights the importance of the interior monk and links outward appearance to interior preparation. Both place and person need to be made suitable - and not just the churches and chapels at Cluny but also the rest of the monastery. I think Peter means to paint a vignette in the reader's mind of a festive household ready for Christmas morning - a sort of medieval Norman Rockwell word-picture. I also suspect that Peter intends an element of emotional longing to be provoked in a Cluniac reader, just as these days a Christmas wreath or a Christmas carol playing in November can spur anticipation of the coming celebrations.

With the Christmas stage set, Peter expands Gilo's depiction of the Christ-child vision. Unlike Gilo's account where the devil appears and is immediately banished without even being seen by the witness, Peter's account presents the devil as the starring character in a sort of horrific comedy, described as a disgusting and filthy little fellow, whining that Jesus won't let him do anything. In Peter's story, Jesus grants the demon the freedom to attack Cluniac monks:"Go ahead, you scoundrel!" said the Son of the Virgin, "Try what you might, so that you stop complaining you are predetermined by my power". ${ }^{11}$ These words deny the essence of Gilo's contention that Jesus specially protects Cluniac space, perhaps reflecting a revised Cluniac attitude. Peter instead notes that the demon admits that he knows he has no chance to penetrate ecclesial space but that he hopes

6o Peter the Venerable, De miraculis, book 1, chap. 15, 50: 'Qua temporis revolutione redeunte, fratres more solito se suaque omnia preparaverunt, et ecclesias ornando, alique monasterii loca aptius componendo, intus et extra festivi apparere sategebant'. In imitation of the papal liturgy in Rome, the celebration of Christmas at Cluny was celebrated by a triple mass - the night, dawn and day masses - which at Cluny, like in Rome, began in the claustral chapel dedicated to the Virgin Mary and progressed to one dedicated to Saint Peter. The liturgy of Christmas day re-constructed Cluny in a metaphorical fashion, by reproducing the liturgy simultaneously taking place at Rome in the ecclesia and buildings of Cluny.

61 Peter the Venerable, De miraculis, book 1, chap. 15, 51; 'Vade, ait Filius virginis, furcifer, et ne te mea potentia preiudicatum lamenteris, tempta quod poteris'. 
to darken other parts of the monastery. He rushes off to the chapter room but cannot get in, because the entrance was too narrow for someone so swollen with pride, and its lintel blocked him when he tries to enter with 'prideful uprightness' (superbum erectum) rather than with the proper 'humble slouch' (humilem inclinatum) ${ }^{62}$ The demon then runs along the east gallery of the cloister to make his way upstairs to the dormitories, but his great size again prevents him from entering. He rushes to the refectory, knowing that he might have a chance to enter since monks would be distracted from their spiritual mission when feeding their body. But again the demon is prevented from entering, due to 'the many barriers created by the reading of the divine words, the many palisades raised by the devotions of the listeners, and the door-bars set by the charity of those serving one another'. ${ }^{63}$ We see that Peter depicts the acts and feelings experienced within the refectory as physical barriers to evil - a making concrete of the intangible. The story finishes with the demon failing to enter any part (officinis) of the monastery; he then flees, completely baffled by his defeat.

While the devil might have been surprised to fail, Peter assures us that a Cluniac reader should not be. But it is worth being a bit sceptical about his retelling. All areas of the monastery were protected against evil, Peter seems to claim, by the historical weight of good conduct within. Since the devil attacks at night, the refectory, for example, would be empty, and thus it could not be the actions of monks in the refectory at the time that prevented the demon from entering. Peter seems to suggest, instead, that the refectory has been quasi-sanctified by the residue of so many readings, so many intent listeners, and so many acts of friendly charity. The idea of the monks' communal action is what ultimately protects the refectory. A monastery united in good conduct, Peter thus tells us, is what keeps Cluny strong. Moreover, intangibles such as charity, which are invisible to the exterior, are conceptualized spatially and as part of the built environment, with cloister and community conflated. Monks are explicitly told that visible and physical parts of the monastery should be understood as having an invisible and spiritual dimension, endowed by their actions with additional qualities such as protection against the devil.

62 Peter the Venerable, De miraculis, book 1, chap. $15,51$.

63 The metaphor is of a barred door (beams/bars repeated three times). The passage reads in full (De miraculis, book 1, chap 15, 51): 'Ibi etiam tot obices divinorum ex lectione verborum, tot trabes ex devotionibus auditorum, tot repagula offendit ex karitate sibi invicem servientium, ut nullo modo ultra procedere prevalens, retro cogetur redire'. 
The connection drawn from the space of the monastery to the practices of Cluniac monks, as well as to their inner thoughts and feelings, highlights the centrality of monastic space in Peter's version of the story. The monastery is not just a battlefield on which the monk's spiritual warfare is fought but is itself one of their weapons to be used against the devil.

\section{Cluny's Didactic Space}

I wish to spend a few final words exploring how stories like this one exchange messages about space and spirituality. Narrative's ability to collapse time is key to understanding the purpose of Peter's retelling of Hugh's vision-story. By presenting the vision as a frame story, by highlighting the context of its original storytelling, and by constructing the story as offering - alternately Hugh's and Jesus's own words, both authors urge Cluniac readers to imagine themselves in the past - listening to Hugh in the chapter room on Christmas Eve or overhearing Jesus in the claustral church of Saint Mary's on an earlier Christmas Eve. The opening lines from Peter's version cited above set up the Christmas celebrations as part of an unending tradition of Christian/ Cluniac liturgical celebration. 'It is the custom of this monastery' he says, making it a present that applies both to the time of his writing and to the time it would be read by a monk in the future.

While the monk is imaginatively time-travelling, what remains stable for him is location. Whether imagining themselves as a monk listening to Hugh in the chapter room, being Hugh in the church of Saint Mary, or being a reader sitting in the northern gallery of the cloister, Cluniac monks of Peter's time (and later) would still be able to look around the cloister and see all the places mentioned - still largely unchanged from Hugh's time. ${ }^{64}$ But after reading this story, they would theoretically see them in a new light, since Peter asks his audience to imagine aspects of the physical environment as monuments to a tradition of virtue. The refectory is not defined by its purpose - a place where you eat - but by its spiritual utility. The chapter room is not just where you talk about monastic business but is a place you cannot enter with 'prideful uprightness'; thus you learn humility. The definition remains largely metaphorical, but the invisible spiritual dimension is made perceptible (the story may also be a hint about a key

64 For a reconstruction of the abbey of Cluny in Peter the Venerable's time, see fig. 6 and 7 (Groupe I, Planches VI and VII) in Conant, Cluny. Les Églises et la Maison, not paginated. Conant's model is questioned by Anne Baud. See her 'L'abbaye de Cluny', 387-399. 
architectural detail about the chapter room - a narrow entry doorway with a low lintel). According to Peter's story, the doorway should remind monks to hold humility in their bodies and in their hearts. A few cracks of a monk's head against the lintel would be enough to remind them to bow their head, but they would still need context to remind them to bow their head with humility. We can conclude that for Peter, space is mute unless you know the stories to make them speak.

This chapter has focussed largely on a single story from Peter the Venerable's Book on Miracles, but similar definitions of space are common throughout. The story reflects a usage typical of monks in daily life when conversation was permitted; a kind of informal learning that would be often transmitted but was only occasionally written down. Hugh's vision had an unimpeachable witness - a recently canonized abbot of Cluny - and Peter's reworking of that vision helped his monks look on their environment with new eyes and new discipline.

\section{Conclusion}

By interrogating what constitutes useful speech and undertaking a close reading of a single miracle story, I have sought to demonstrate that we can see the medium of narrative story-telling as key for monks to communicate edifying speech to one another. Peter the Venerable's retelling of the Hugh vision story and the literary antecedent in Gilo's Life of Hugh both note that their written accounts are intended to preserve in text what an abbot of Cluny had told in person. The bulk of the Book on Miracles, with its emphasis on establishing a chain of transmission, indicates that not just abbots but also Cluniac monks were constantly sharing stories with each other. The changing content of Hugh's visionstory also reveals what sorts of ideas may have been communicated between Cluniac monks. While Gilo's account highlights liturgical purity, Peter's retelling suggests his particular interest in emphasizing Cluny's need to be a strong unified community, perhaps linked to his interest in promoting Cluniac harmony in the aftermath of abbatial and papal schism. The source of Cluny's miraculous protection from the devil is the everyday practices of the Cluniac brothers. It is not the unattainable perfection of Christ or a saintly abbot who is to be imitated. Rather, agency is placed directly on the community of normal monks to uphold Cluny's lofty spiritual position. A final idea, which deserves further exploration elsewhere, is the affective component of Peter's narrative. 
As a good rhetorician, Peter understood that appealing to emotions such as love, sadness, humility, fear, or disgust can be more effective in emphasizing a point than logic. Emotions are more than just a textual strategy, however. They are also the content of his message. In this and his other stories, Peter communicates the proper emotional disposition of monks: be fearful and be tearful, love and trust your fellow monk, or else you will fall prey to ravaging demons.

\section{Appendix A: Regulations Concerning Speech and Silence}

\section{Peter the Venerable, Statuta}

\section{Concerning silence in the monastery}

It is instituted that in the infirmary of Cluny, which is divided into five areas under one roof, silence must be maintained differently in each, so that the one area where the brothers die, which is in the middle of the building, and in that part which is above it, silence or conversation happens in the customary fashion. In the three other parts, the silence of the cloister must be maintained. It is the same in the cells of novices and in the attached novice's cloister, or the workshops - excepting novices or their master, who speak where and when they are accustomed to speak and excepting also any visiting bishops and abbots, or the major prior and the sub-priors (the custodians of order), who themselves are able to speak in the area of the aforesaid cells of the novices only in the presence of a second custodian. Let ceaseless silence be maintained in every workplace, excepting a single master for each workroom and excepting those working on the new church and their work sites. Let claustral silence be maintained, moreover, in the cemetery and the cloister of the cemetery, in all the sacristies and on that path which leads to the older elevated rooms, which are next to the major church and in adjacent places, excepting the abbots and priors for whom in these particular places it is suitable to speak in the traditional manner.

The reason of this institute was chiefly the necessary usefulness [utilitas] of silence for every religious, who cannot be called nor be a monk without it observed in a suitable manner. The admiration of silence is so great in the Holy Scriptures that, among the countless praises of it, the outstanding prophet Isaiah himself said, 'Silence is a reverence of justice'. But since the silence of the Cluniacs has been truly degenerated for some time on account of the frequency of secular affairs and the multitude of visitors, it seems necessary that this period of silence, as is laid out above, be instituted. 


\section{Concerning silence during Lent}

It is instituted that during the time of Lent, continual silence be maintained for all of Lent, adding three extra days of silence, which are the third and fifth ferial days, and the Sabbath, on which days speech used to happen in the cloister according to former custom.

The reason for this institute was the reverence for such sacred days, since it did not seem sufficiently religious that the virtue of silence was publicly adulterated by unnecessary speech on those days of the highest abstinence and every virtue.

\section{Concerning conversations in the cloister}

It is instituted that, the second of the periods for speaking about useful things in the cloister is removed every day, year round.

The reason for this institute was the utter lack of its usefulness [utilitas] or necessity; it was not only the increased leisure but also the greater danger for the monks when another hour of the day was freed from useful and necessary endeavours. For speech lacking usefulness, or rather, harmful speech filled the space of that time, which now salubrious taciturnity takes for itself to fill with readings and divine songs.

\section{Concerning silence during the meal}

It is instituted that silence is maintained everywhere and by everyone at the table as if in a regular refectory. But if anyone comes from outside the refectory for someone eating regularly, let him get up and when he receives him, he shall speak to him standing as much as it is necessary, but after he sits down again, let him be silent as before.

The reason for this institute was the apostle ordering this rule even for the laity, that each person, 'eat his bread in silence' and Saint Benedict commanding and saying to monks, 'Let theirs be the greatest silence' at the table, and the monks of ancient and modern times, who, wherever they eat, must not reduce at all the rigour of silence. And it is not respectable for Cluniacs to seem less religious, through whose efforts the monastic way of life (having dwindled for many years) flourished again in Gaul, Germany, England, Spain, Italy, and almost all of Europe, whose inveterate tepidness was newly inflamed by divine command and with the assistance of His grace.

\section{Concerning the enclosure of claustral precinct}

It is instituted that no cleric or lay person may enter into the cloister or the rest of claustral precinct unless in order to do something or for looking 
around the buildings, as respectable guests are accustomed to do, or for healing the sick lying in the infirmary.

The reason for this institute was the frequent comings and goings of the clergy, the laity, and especially the servants, for any reason, to such an extent that it turned the cloister almost into a public thoroughfare and, in coming and going, they now seem almost to be no different from the monks.

\section{Concerning servants in the infirmary}

It is instituted that none of the lay attendants, as used to happen, may look after the sick or anyone eating in the infirmary, but only monks or bearded conversi.

The reason for this institute was the greater respectability of monks cohabitating with the lay brothers [conversi] than with lay servants and that the lay brothers should spend their time serving the brothers, not so that they have the opportunity to steal what was left over from the table of those eating in the infirmary, just as servants formerly would pilfer from the brothers openly and furtively for their wife or children or for any members of his family living in the town. It was also for this additional reason - that gossiping to lay people in the manner of a lay person, these servants disclosed the secret things of the monastic order or the regular disciplines, which either they saw or they heard from someone, while standing around in their regular duties.

\section{Concerning manual labour}

It is instituted that manual work - so holy and ancient - ought to be restored in some small fashion whether to be done in the cloisters themselves or in another place where they are respectably removed from the sight of secular affairs. On all days but feast days (when it is not suitable for them to work), brothers must always undertake useful work wherever they are.

The reason of this institute was, that 'idleness', called by Father Benedict 'the enemy of the soul', $[R B, 48]$ resides in so many of our monks, especially those who are called conversi, with the result that in the cloisters or outside the cloisters, apart from reading a little and writing only rarely, either they sleep, leaning against the walls of the cloister, or on account of their [idleness] they fill almost their whole day with vain, hateful words and often (which is worse!) with slanderous speech, - as I could say thusly, 'from the rising of the sun until its setting' [Ps. 49:11] or more precisely from the middle of the night when one may do so with impunity. 


\section{Concerning silence in small monasteries}

It is instituted that in houses where there are not able to be twelve brothers, complete silence must be always maintained in the refectory and dormitory, at the very least, as well as in the cloister from the hours of Vespers until the third hour [tertiam] of the next day. It is long established that silence ought to be maintained by everyone at all times and everywhere in every church.

The reason for this institute was that if brothers in such places either were unable to maintain the entirety of our customary practices [ordo] or they did not wish to, then at least they should retain some semblance, some vestige, or particulars of them, lest by filling the whole day with trifling words and acts, they be seen as no different from seculars.

\section{Appendix B. Two Accounts of Abbot Hugh's Vision of Jesus in the Marian Chapel}

I. Peter the Venerable, De miraculis, book 1, chapter 15 (c. 1142)

The story the Blessed Hugh narrated in chapter at Christmas Vigil.

It is the custom of this monastery to undertake the Nativity of Our Saviour with a singular affection and more devoutly than other solemnities, and to celebrate it together with the spirits of angels through the harmonies of our songs, the prolixity of the readings, by the lighting of many additional candles and - far surpassing all others in importance - with a special devotion and with a great outpouring of tears. After the change of seasons, the brothers in their accustomed manner prepared themselves and everything necessary and, by ornamenting the church and decorating all the places of the monastery in a similarly suitable fashion, they strived to appear festive both inwardly and outwardly. The blessed and venerable father Hugh was then still alive, though close both to corporal death and also to the eternal life after death. With the celebrations about to begin, he entered the chapter where the brothers had already gathered and said these words to all:

You know, brothers, that Jesus, our benign saviour, has chosen to be among us for the celebration of his nativity and your liberation, and he awaits with great joy the worship of your devotion. But also you know that our wicked enemy, jealous of your happiness, labours as much as he can to overshadow our splendour with dark clouds and to diminish, even if only a bit, the glory of so great a feast! For a certain brother, he continued (and by this he certainly meant himself to be understood as this brother), saw on this night the eternal virgin, the Mother of Mercy herself, holding 
against her softest breast the son whom she bore this very night, and next to them was gathered a crowd of holy angels bathed in a brilliant light. The God-child rejoiced and exulted with great joy and showed the happiness of heart with the gestures of his glorious body and the clapping of his hands. And turning to his mother, he said to her, 'Do you see, my mother, that the coming night, shall be brightened by the joys of my birth, by which both the oracles of the prophets and the praises of the angels will be fulfilled and everyone in heaven and on earth will rejoice together due to my birth from you. Where now is the treachery of the damned enemy? Where is his power, which dominated this world before this singular joy?'

With his name evoked and emerging from his hiding place, an impudent figure - disgracefully filthy - presented himself at a distance, and begged with great wails and lamentation that he be admitted. This he said, sworn as a vow, that in his manner, he would be strong enough to darken in some way even the joys of [Cluny's] great brightness, which he envied. And he said, 'Even if I will not be received into the ecclesial space, I might be admitted into another place of the remaining precincts (reliquarum officinarum loco)'. 'Go ahead, you scoundrel!' said the Son of the Virgin, 'Try what you might, so that you stop complaining you are predetermined by my power'. And he [the devil] made for the archway of the chapter room and when he tried to go in, he was unable to enter. For in fact, in that place he found himself so swollen and the entrance of the chapter room so narrow that he was not in any way able to go inside. Truly inflated by the ancient curse of Pride, he was not able to pass through the humble entrance, since the entrance does not accept this prideful erectness, but only a humble bent-over posture. Then he turned his steps towards the dormitory of the brothers, confident that he would be able to disturb the brothers with his usual phantasms and tried to enter. But again he retreated - repelled due to his great size. And then he took himself towards the refectory - filled with the hope of injuring the brothers and expecting that even the small attention paid to the body there might lead to a large inattention of the mind. There also, he attacked the many wooden barriers created by the reading of the divine words, the many wooden palisades raised by the devotions of the listeners, and the door-bars set by the charity of those serving one another, with the result that he was unable to advance a step, and was forced to retreat anew. Repelled likewise by all the precincts [officinis] of the monastery, this pestilential one fled in retreat, before the sight of the most pious Redeemer and the glorious Virgin Mother, filled with such shame as was suitable.

These words, preached to the brothers by this saintly man, revealed the wickedness of the evil spirits raging against this place and the indulgence 
of the Lord protecting it. Our dangerous wicked enemies, although they lay snares generally for everyone, pursue even more so those newly converted to the monastic life. They - so envious - certainly do suffer from the progress of veterans, but they keenly feel, as if a recent open wound, the aforesaid monastic conversion of new recruits.

\section{Gilo of Toucy, Vita Hugonis Abbatis, chapter 6 (ed. Cowdrey, 96) (c. 112o)}

It was the turn of the second last year before the death of Saint Hugh and the movement of the sun had just introduced the day of the birth of our Lord. As was customary, the father was preceded by the brothers into the chapter room and he declared them to be the stronger since, with a stumbling gait, he was unable to stand upright for long. The father, in tears, exhorted the tearful audience to fulfil, with God as their shepherd, their good work with undivided passion, knowing that the greater glory of eternal reward would follow this great labour. In addition to other matters, he stirred up the emotions of those listening by speaking about a certain vision, but he kept silent about the name of the person relating this vision, whom we believe to be none other than himself [Hugh] who related it. Hugh recounted:

A brother saw the mother of Mercy in her oratory - the most blessed Mother of God carrying the divine infant in her illustrious lap, who, joyfully applauding with his earthly hands, said, 'Behold, this night, which is entirely dedicated to me, reveres my birth and foretells the coming glory of Heaven, the peace for all humanity and that forgiveness will come to the prophets. This night wages war for my glory. This night flashes with the brightness of great lightning. Where now is the wickedness of the wicked enemy, which had been accustomed to rejoice before I, the sun of Justice, arose? I arose from you, $\mathrm{O}$ renowned mother, divine in my lineage and royal in my dignity'.

When Jesus, who held the aforesaid [devil] in his power, had said these things, Hugh commented, he seemed to see the devil sitting nearby, who corrupts thusly! 'Be ashamed, tempter, and flee! My praises (praeconia) with which this beloved house reverberates, bar you as dishonorable'. Chided by these words, that confounded one withdrew far away.

And then the boy, along with his pious mother and surrounded by the angelic army celebrated the illustrious solemnity with you, my beloved brothers. Run towards the path of the Saviour with mouth and soul rejoicing!

This father - on the cusp of his departure - offered these words as a toast (propinavit), pouring them a drink intoxicating their hearts with sobriety, and not long after this his [eternal] rest was foreseen, which a vision proved, seen by a lay workman (laboriosa seculi) in the region. 


\section{About the author}

Marc Saurette is an associate professor of Medieval History at Carleton University. His research interests revolve around the lives and literary production of the monks of Cluny, ranging from the tenth-century of Odo of Cluny to the twelfth-century of the abbot Peter the Venerable and of one of his monks, Richard of Poitiers. Through the writing of these monks, he studies the processes of institutionalization and the cultural implications of the literary and scholarly community of Cluny. His researches include Peter the Venerable's notion of friendship, the modern tradition of Richard of Poitier's Chronica, and medieval ideas of customs and customary. He is working on the first complete study, critical edition, and translation of the works of Richard of Poitiers and undertook the editing, translating, and commenting on the opera omnia of Peter of Poitiers. 
